\title{
The Circular Economy of the Islamic Group Lending Model: Lending Money for Garbage in Return
}

\author{
Yaser Taufik Syamlan \\ Head of Islamic Microfinance Department: \\ TazkiaInsitute, Bogor, Indonesia \\ yasersyamlan@tazkia.ac.id.
}

\section{Sakinah}

\begin{tabular}{|ll|}
\hline Submitted & $: 09-11-2020$ \\
Accepted & $: 01-12-2020$ \\
Published & $: 29-12-2020$ \\
\hline
\end{tabular}

Assistant researcher at Islamic Microfinance Department :

TazkiaInsitute, Bogor, Indonesia.

\begin{abstract}
The Model of Group Lending has been flourishing in the Microfinance Industry. This model has been used widely to serve the needy and un-bankable group of people by lending money plus interest addition. Islamic finance also embraces this model by omitting the interest and applying the Qardul Hassan to finance the members' daily needs. This divine scheme's problem is the microfinance's sustainability since they have a burden to bear the operational cost due to the non - interest feature of the financing. This paper tries to solve this problem by utilizing the household garbage as the media to repay the Qardul Hassan financing to the Islamic Microfinance Institution (IMFI). This would enable to create more added value product, selling it to get more income and achieving the organization sustainability.
\end{abstract}

Keywords: Group Lending, Circular Economy, Garbage Group Lending, Islamic Microfinance

\section{A. Introduction}

Talks on reducing poverty in several countries are still important, mainly among developing countries (Barder, 2009). A survey conducted by the International Poverty Center (IPC) shows that the growth of global poverty, from a total of 237 countries, 80 developing countries can only reach the line of low and middle income during 1984-2001 (Son, 2007). Poverty reduction is often a practical solution to encourage economic growth (Barder, 2009). However, economic growth in developing countries is different, both over time and across countries. The performance differences are due to variations in growth parameters, such as average income growth or consumption level (Son, 2007).

The number of low-income countries correlates to the high rate of poverty. For instance, Prescott (1997) found a small group of categorized poor, called Group Lending (GL). They borrowed money to make ends meet but had no guarantee. His model can be categorized as a part of the microfinance model. A loan group aims to increase income and expand financial markets by providing financial services (primarily loans) to small communities (Armendariz de Aghion\&Morduch, 2000). The presence of group lending can improve and expand microfinance services. Group lending also fosters a sense of shared responsibility for its customers and can reduce the risk of loan defaults 
(Feder\&Huppi, 1990). In the implementation of the model, all members of the MFI will be responsible for the loan of a single member. This implies that if the member is unable to the loan, the other group members will be responsible for the loan. If the group cannot fulfil the shared obligations, all members are cut off from access to loans in the future (Prescott, 1997).

There are currently two types of applications regarding group lending in microfinance, namely the conventional group lending (CGL) and Islamic Group Lending (IGL). CGL enforce interest rates on borrowers. In this lending group contract, customers have difficulty with the interest rate that depends on the loan's size and the members' payment strategies (Baland et al., 2013). The latter is the implementation of Islam using the concept of Qardul Hassan. In this concept, the borrowed money to be returned to MFIs has the same amount. There are some loans in Islam's implementation using other Islamic finance contracts and larger loans or projects (Ghafar et al., 2013). When looking at the two concepts of applying loan groups above and referring to the purpose of the presence of lending groups who want to reduce social inequality in the community (Schurmann\& Johnston, 2009) then the application of Islamic concepts by correcting conventional concepts, become alternative microfinance relevant to the purpose of group lending on microfinance (Kholis, 2018).

With the emergence of these issues, IMFIS cannot rely solely on the costs of the grant. Therefore IMFIS must obtain fees from other sources in order to be able to run the Islamic lending group with good operational management and continue to use the essential Islamic financing instrument so that it remains in line with the purpose of the presence of group lending for the poor. Recently, the discussion of circular economic theory has become one of the most popular economic discussion topics (Geissdoerfer et al., 2017). However, economists have discussed the concept of circular economic theory since the 1970s. The shift in a linear economic system to a circular economic system has a high potential for developing the world economy (Wautelet, 2018). In world economic problems, several social expectations have not been fulfilled because of the many problems that emerged, such as high unemployment, poor working conditions, the company's financial instability, and others. With these problems to overcome, the circular economy concept became the spotlight of solutions that have a high potential for business people and stakeholders (Geissdoerfer et al., 2017).

Until 2012, in the world economic forum, Ellen MacArthur Foundation (EMF) and McKinsey Company published a potential report of a linear economic transition to circular economies that benefit from creating economic profit opportunities worth the US \$ 630 billion per year (Wautelet, 2018). Currently, the circular economy is gaining momentum because of the promise to overcome the contradictions between economic prosperity and the environment (Pomponi\&Moncaster, 2017). For example. A survey conducted by Scotland's Environment, the total amount of household waste produced in 
Scotland in 2016 was 2.50 million tons, an increase from the previous amount of 30,181 tons $(1.2 \%)$ in 2015 . This is the third year in a row of an increase in the amount of household waste produced. With a high amount of household waste, concern ofenvironmental hygiene, and a high potential for environmental pollution, the circular economy concept is suitable for overcoming this problem. Household or corporate waste can have value, which increases to produce a fair value back to the one who collected it because the processing of recycled waste will be more valuable than the waste that is directly traded (Linderhof, Kooreman, Allers, \&Wiersma, 2001). However, the principles of joint establishment lie in better management of resources. Therefore, the role of environmental coaching is significant because of its high environmental impact, which also offers significant opportunities for reducing energy use, greenhouse gas emissions, and waste production (Pomponi\&Moncaster, 2017)

The problems surfaced in the operation of group lending require additional operational costs to support the purpose of lending groups in the poor community. Also, feasible opportunities present for household or corporate household waste to be recycled. Applying the circular economy concept to these problems might be a suitable solution. In this study, the author will create a combination of Islamic group loans and waste management systems using the circular economy concept. In this research, the author is trying to develop a "Money For Garbage in Return Lending" based on the canvas business model. Researchers will develop procedures in the application of the program "Lending Money For Garbage in Return". At the end of this study researchers will discuss how to analyze sharia problems related to the program "Lending Money For Garbage in Return."

\section{B. Literatur Review}

\section{The Circular Economic Theory}

The circular economy system is a restoration industry system. The model is made to redesign the business model by utilizing the waste products from the business that has been run (Macarthur, 2013). A circular economy is a change in the environment in the face of global needs for economic ecology. It requires human economic activities consistent with the three basic principles of reducing, reusing and recycling(Lahti et al., 2018). Like the basic principle of a circular economy, the system aims to design waste into a product outline re-optimized for its benefits (Macarthur, 2013). The presence of the circular economy concept is a paradigm for economic development. Besides, it is also a response to the unsustainable conventional economic model using a linear economic system called "take-make-dispose". Therefore circular economy replaces the concept with a business model such as "end-of-life ", which can achieve sustainable development's economic goals and beckon the creation of environmental quality, social equality, and economic prosperity for present and future generations (Berg et al., 2018). Following is the pattern of circular economy with the concept of "end-of-life" : 
Figure 1

The Concept of Circular Economy

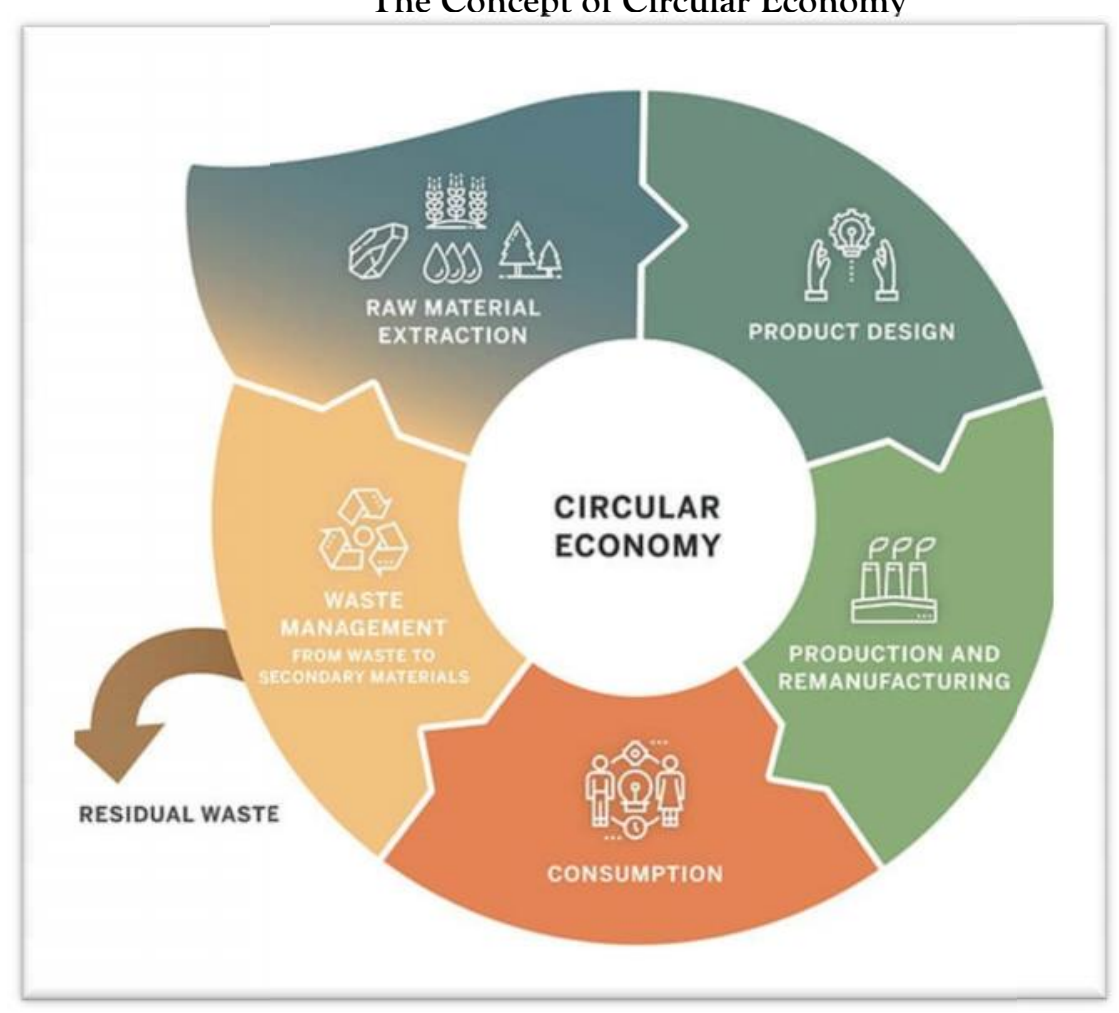

Source: (Berg et al., 2018)

It can be noted that the circular economy system pattern above starts from the selection of production raw materials that will be produced by entrepreneurs. They also have to choose product materials that can later be used with a more extended period. The next process is product design; in this process, entrepreneurs plan their products. The planned product is then produced so that the production result can be used or consumed by the market. After the product has been used, the next process that distinguishes the circular economy from a linear economy is the processing of waste production. In a linear economy, all the results of production waste will become unused waste, but in the circular economy concept, the waste that has been consumed can then be managed again by going through the waste management process first where the waste will be sorted according to the condition of the waste, if the waste categorized as not suitable to be recycled, the waste will be burned or eliminated (Berg et al., 2018)

The circular economy concept is not new because academics have discussed it and previous economic practitioners (Behrens et al., 2016) in the 1970s economists discussed the economy's circular theory. The result was that this system had a high potential for developing the world economy. Until 2014, Europe became a pioneer in applying the circular economy concept implemented in the "zero waste for Europe" program. Following the development of economic activity in Europe, many European countries had applied the circular economy concept strategy in their business sectors, such as Finland, Netherlands, 
Scotland, and France. In 2016 Finland became the first country in the world to issue a circular economy road map facilitated by Sitra Studies in collaboration with business sector ministries and stakeholders (Wautelet, 2018). Throughout the world, governments, entrepreneurs, and academics have widely used the circular economy concept, although it has not been used consistently (Behrens et al., 2016).

Figure 2

Sample of Circular Economic Road Map in Finland

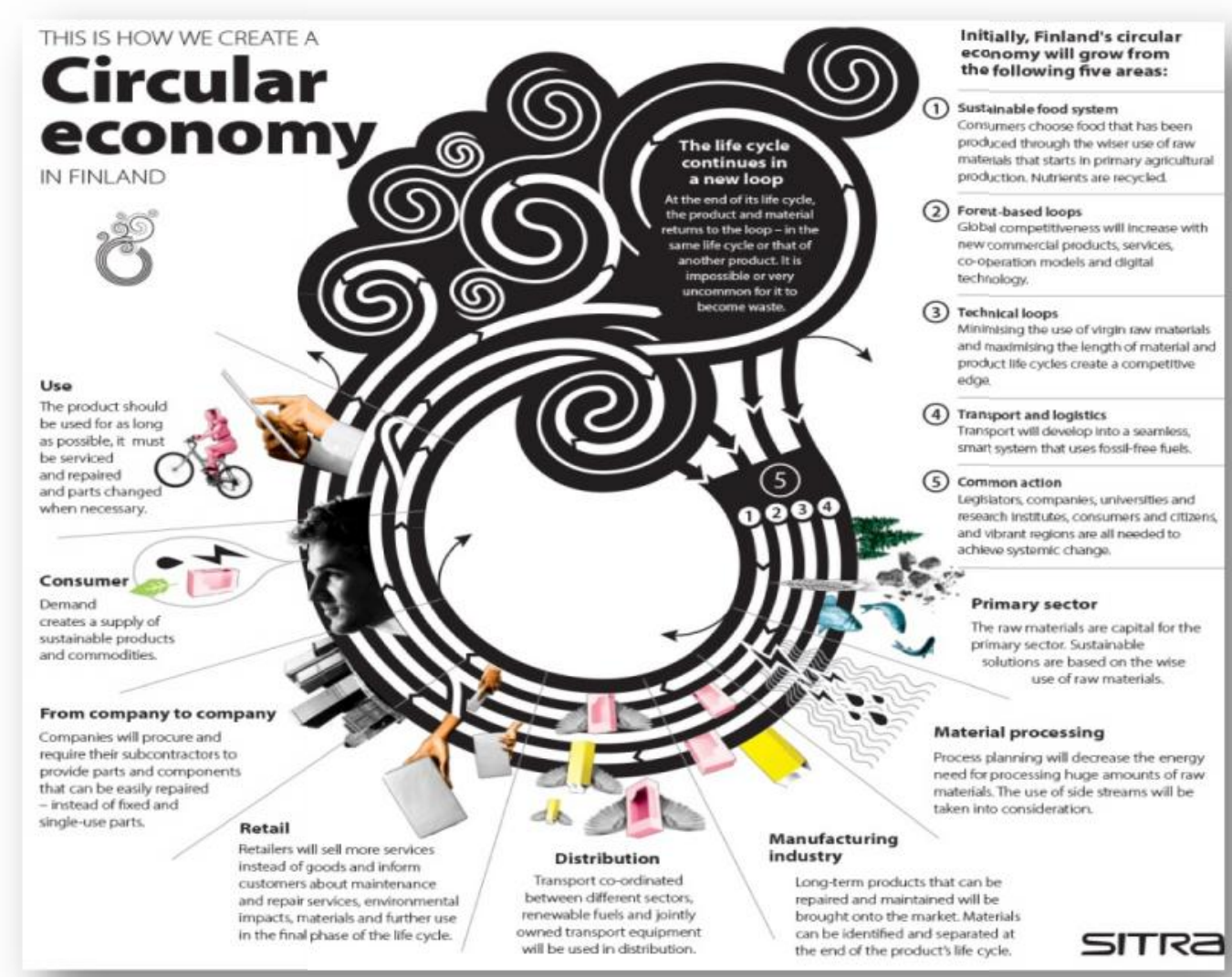

Source : (Sitra Studies, 2016)

Above is a circular economy roadmap designed by Finland in 2016 for economic sustainability up to 2025. In the road map issued by Finland, five fields focus on economic development through a circular economy system. The first is a sustainable food system, where consumers choose foods that have been processed from natural raw materials and recyclable nutrients. The second is a forest-based circle. Third, technical circles minimize the selection of raw materials that only last temporarily and maximize raw materials that can last longer. Fourth, the use of transportation fuels will not rely on fossil raw materials. The last is a joint action, where all elements starting from the government, entrepreneurs, 
and consumers must pay attention to the above points in carrying out economic activities (Sitra Studies, 2016). However, since Finland is a developed country with a sound waste management system, it excludes the road map's financial industry's circular economy. This creates a gap, and this research will try to combine how the financial industry also can benefit and make more value-added in the concept of a circular economy.

\section{The Group Lending System}

Microfinance is a provider of financial services for the poor and is called micro because the number of incoming transactions is only on a small scale. This financial service has consumers whose loan size is small but has a significant default risk scale because consumers do not have financial guarantees. Therefore the formal financial sector avoids this market (Prescott, 1997). In China and Russia and some countries in Europe, the relationship between microfinance and lending groups has a strong link to programs that focus on poverty (Aghion, 2000). However, the absence of a formal sector in this market has made non-profit organizations that lead the microfinance sector with the pretext of poverty alleviation, often maximizing their profits. The reason is also found in the incompatibility of conventional products the microfinance sector such as group lending (Prescott, 1997).

In group loans, several things become obstacles for MFIs to carry out microfinance services, such as cost of forming groups to train borrowers to understand loan group procedures, and high supervision costs because they have significant risks (Kodongo \& Kendi, 2013) so that conventional group loans in the application, have contracts that are complicated by interest rates that depend on the size of the loan (Baland et al., 2013). However, economists are particularly interested in group loan services because the loan models pioneered by Grameen banks in Bangladesh and BancoSol Bolivia have successfully provided services to small consumers to develop their needs or businesses. (Aghion, 2000). Besides that, the loan group's shared responsibility system makes the researchers argue that the borrower's punishment that violates the credit risk is acceptable. However, the MFI has the opportunity to have optimal use of loan funds by the borrower, because it is predicted that in the future the credit application is no longer present if one member fails to pay (Kodongo \& Kendi, 2013).

The group loan model was first applied in Bangladesh; the basis of the model's description is that shared responsibility is the key to the loan group concept's success. Because it is different from conventional bank systems, microfinance programs such as lending groups provide loans to borrowers. All lending group members are responsible for the debts of every single member in their group. In this practice, microfinance programs depend on accountability and mutual trust between group members. In this group, the poor often do not have financial guarantees to guarantee default (Li et al., 2009). However, setting interest rates applied to conventional lending groups becomes irrelevant to the presence of group lending for the poor (Prescott, 1997), to see how interest rates vary based on the size of the loan along with examples of the model, each member and a group with the same number of people with the same wealth need a loan for a project or to meet 
members' needs, the interest rate depends on the MFI's assessment of possible payments/equivalent and to the faction of those groups who will pay the loan (Baland et al., 2013).

\section{The Islamic Group Lending}

The emergence of microfinance requires an instructive examination from an Islamic perspective. Lending and financial accessibility to the poor is very relevant to the concept of Islamic finance because it places the responsibility for social welfare and more outstanding religious commitment to achieve the goals of world economic development. The concept of group lending is not a subject that is alien to Islam. In ancient times ibn Khaldun has described the concept of "Asabiyah or Social Solidarity" in his famous book, alMuqaddimah. This book discusses the concept of social solidarity designed neatly within the framework of social capital based on group loans. Therefore, the concept of social capital and approaches based on group lending can be used well by SMFI to find the most effective and efficient ways to provide financing for the poor (Dusuki, 2006)

Islamic lending group using the application of services is not much different from the conventional group lending. The difference is that conventional group lending is applied to loan repayments using interest rates that adjust from the loan amount (Baland et al., 2013). It can cause the borrower who initially wants to cover his needs from the loan, but instead will potentially be in debt more incredible than the interest rate on loan (Prescott, 1997). However, the Islamic group lending concept in its application uses the concept of Qardul Hassan. In this concept, loan customers to SMFIs are paid according to the number of loans, which are also not added, but some loans with Islamic concepts use other Islamic finance contracts for larger loans or projects. (Ghafar et al., 2013).

According to Khan (2008), in order of Islamic Microfinance Institutions (IMFIS) to achieve success from group lending using sharia contracts, several things need to be considered by the lending group, namely:

a. Member Monitoring: Each loan group member must have a different level of ability to repay loans. Therefore members of one lending group must ensure that each loan fund borrowed by other members is appropriately managed so that the loan money is safe and returned.

b. Social Relations: social ties between loan group members have to be healthy. If one of the members cannot pay the loan, other members' sanctions from IMFIS will be received, namely in the form of not being able to get other group lending members to get loans.

The success of group lending in reducing poverty will be difficult to apply to areas where the community's social relations are low. However, the success of lending groups has been influential in several countries such as Bangladesh and Asian and African countries (Khan, 2008)

\section{Research Methodology}


This study used qualitative descriptive research. The research source came from the exploration of international journals relevant to the research title and related to research keywords, such as poverty, circular economic theory, and Islamic group lending.

In this study, researchers used two data types: the primary data, namely the type of data sourced directly from the publisher or the main source. Researchers' primary data include data sourced from Sitra Studies in the form of a road map of circular economy published in 2016. Researchers' data types are secondary data, namely the type of data sourced from second parties that are not sourced from data publishers. Researchers' secondary data is international journals, such as Journal of Development Economics, SAGE Publications, Journal of Industrial Ecology, World Bank Research Observer, and others.

In this study, the researcher used descriptive analysis technique. Descriptive research is a form of research that describes existing phenomena, both natural phenomena and human-made phenomena. This phenomenon can be in activities, characteristics, changes, relationships, similarities and differences between one phenomenon and another. Descriptive analysis is also a study that attempts to describe and interpret something. Descriptive research is designed to obtain information about the research conditions being carried out (Linarwati dan Minarsih, 2016).

Sulipan (2017) the following are the steps in conducting a descriptive analysis;

a. Identification of problems

b. In identifying problems, researchers see the poverty that is still not resolved well, especially in developing countries. Even though the services of IMFIs have been present, namely Islamic group lending, Islamic finance instruments' application to Islamic lending groups faced problems. This problem arises from the lack of operational costs, thus becoming a negative impact on IMFI management.

c. Formulating Problems

d. The process of problem formulation is done by exploring international journals relevant to the study. The researcher then concludes the problems of the research object then provides a solution to the problem.

e. Theoretical Basis

f. In searching for the theoretical basis, in this study researchers used references to journals or previous research that had discussed the variables in this study, namely poverty, Islamic group lending, and circular economy.

g. Conclusions/Research Results

h. In compiling conclusions or the research results, researchers use the steps that have been written above, and the researcher provides a solution to the problems identified in this study.

\section{Discussion}

This section will address three main issues that are stipulated above. This discussion section will cover the big picture of the program in the form of Business Model Canvas, the general program procedure, and the sharia issue of this program at a glance. 


\section{The Program Lending Money for Garbage in Return}

The beauty of the Business Model Canvas is to simplify the business idea into nine building blocks. It contains the marketing side (including value propositions, customer segments, customer relationship and channels); the financial side (revenue stream and cost structures); as well as the operational side (key activities, essential resources as well crucial partners). The "Lending Money for Garbage in Return" is the modifications of the original Islamic Group Lending (IGL) scheme. The original IGL is based on Qardul Hassan contract, which lends money and pays it back with money. To give the bird's eye view of the "Lending Money for Garbage in Return" in the form of BMC program is:

Figure 3

The Business Model Canvas of "Lending Money for Garbage in Return"

\begin{tabular}{|c|c|c|c|c|}
\hline Key Partners & KeyActivities & Value Proportions & Customer Relationship & Customer Segments \\
\hline The Group Lending Members & Financing Analysis & \multirow{11}{*}{$\begin{array}{l}\text { Group Lending Member Side: } \\
\text { Get Money Pay Garbage } \\
\text { Economic Empowerment } \\
\text { Religious Empowerment } \\
\text { Riba Free Loan } \\
\text { Group Lender: } \\
\text { Higher Value Added } \\
\text { Higher Business Scale } \\
\text { End User: } \quad \text { Eco Friendly Product } \\
\text { Halal Product }\end{array}$} & Group Lending Members: & \multirow{11}{*}{$\begin{array}{l}\text { Segment of End User: } \\
\text { Individual Buyer } \\
\text { Industrial Buyer }\end{array}$} \\
\hline \multirow[t]{10}{*}{ Marketplace } & Money Disbursement & & Weekly Meeting & \\
\hline & Household Garbage Collection & & Religiuos & \\
\hline & Re-cycling Garbage & & End User & \\
\hline & \multirow[t]{3}{*}{ Marketing Recycle Product } & & Hotline & \\
\hline & & & Post - Purchase Service & \\
\hline & & & & \\
\hline & Key Resources & & Channels & \\
\hline & Account Officer & & Marketplace & \\
\hline & Re-cycling Machine & & Social Media & \\
\hline & Storage & & & \\
\hline \multicolumn{2}{|r|}{ CostStructures } & & Revenue Stream & \\
\hline \multicolumn{2}{|r|}{ Initial Fund } & & Income from Recycle Produc & \\
\hline \multicolumn{2}{|r|}{ Re-cycle Machine } & & Voluntary Donations & \\
\hline \multicolumn{2}{|c|}{ Gargabage Storage \& Transporter } & & Administration Fee & \\
\hline
\end{tabular}

Source: Authors

\section{The Marketing Side of "Lending Money for Garbage in Return}

a. Value Propositions

The value propositions of the "Lending Money for Garbage in Return" will be divided into three stakeholders: the IGL members, the IGL operator, and the end-user of the recycled product from this program. The IGL members will mainly get money without any addition of interest or riba under the Qardul Hassan. This money can be used to full fill their daily need. The principal value proposition is paying the garbage with equal value with the loan amount (this matter will be explained later in section 4.2). The IGL member can collect their household waste which has equal value with the instalment amount. The IGL should also empower the religious side of the members like the BaitulTamkinTazkiaMadani in Sentul, Indonesia. In every weekly meeting, the members 
have to recite Al-Quran Verses of Riba, AsmaulHusna (The Name of Allah), and the oath to be committed to pay loan repayment. Last, According to the Mukhlisin (2019), business training, and personal financing literacy inform of economic empowerment program to uplift their economic and religious welfare.

In the IGL Operator, this program mainly adds higher value-added in the business operation. Before undergoing the program, those IGL operators are in hardship due to lack of income from the member due to the Qardul Hassan contract. These days that IGL operator only relies on the administration cost of financing (which is very little) and the donation either Zakat, Waqaf, or Shadaqah from the donator. The existing IGL operation has no value-added from collecting money from members or donators to the distributing fund thru financing. This program's main feature is paying debt by giving garbage will escalate IGL operator value since the recycled product would have a higher price and give more income which more giant than the financing admin cost that stipulated above. The price of plastic granule, for example, would be more interesting than that cost.

Moreover, the income of the recycled product is even higher if we compare to the interest that charged in the conventional group lending. Another impact of this program is the higher business scale. The new business model will require more resources and management skill. The IGL operator should have new investors to buy the recycling machine and outlay the capital for the storage to keep the garbage save before recycling it. Moreover, IGL operator should assign new employee that handle the sales of the recycled goods. All in all, the scale of business is improved from only lending and taking back the money without any profit to a more profitable business that processed the garbage to be the end product or the raw material.

The value proposition for the end-user of the recycled goods is an eco-friendly and halal certificate. The recycled product basically will help the ecosystem to extract the waste without disrupting the ecosystem itself. The end product will again be recycled after the economic age passed. Besides the eco-friendly product, the recycled product should be labelled halal to support the halal industry value chain.

\section{b. Customer Segments}

The IGL is established for those who are in need. The formation of IGL needs several processes to make sure that it serves the right segment. The IGL Founder should do some initial survey to see the surrounding environment around the potential IGL Members if the survey result shows that the people income is lower than USD 1 per day and the amount of waste are considered enough to support the program than this IGL can be formed.

On the side of an end-user of the product that is resulted by the IGL, the recycled product will be targeted to both individual buyer or industrial buyer depending on the product produced by the operator of IGL. If the product is the end product material that consumer can directly use without any production process, it will be directed to the individual consumer. However, if the recycled product of IGL operator in the form of work in process product or half raw material like plastic granule which the individual consumer cannot directly use, this kind product will be sold to the industrial buyer.

\section{c. Customer Relationship}

To maintain the customer relationship to the member, this IGL will create weekly "Majlis Meeting" that will help both IGL operator and member. This weekly meeting will 
help the operator for collecting garbage as a return of the loan. While for the member, it will increase their religiosity from time to time since they will recite Al-Qur'an and AsmaulHusna. This weekly meeting will also help the members in terms of skill improvement by way of training conducted by the operator.

On the end-user side, both individual and industrial buyers, to maintain the relationship and create the buyer-seller bond, the IGL operator should prepare the hotline as a virtue for customers curious about the IGL operator's product. Furthermore, the OGL should also establish the post-purchase service to handle all customer complaints and hardship.

\section{d. Channels}

The channels are usually representing the marketing line that used by business entities. In this case, to market the product, the IGL operator should post their product in a marketplace like Alibaba or some regional marketplace such as JD.ID, Shopee, Lazadda, and Tokopedia. This option should be optimized fully since the cost of making its market place is higher than joining to the existing market place. Additionally, the sales can be made by advertising via social media such as Instagram, Facebook, and soon. This channels may grab two kinds of customer: the donator of the program and the end-user, especially the individual customer.

\section{The Operation Side of Lending Money for Garbage in Return a. Key Partners}

This program needs several key partners who are the IGL members and the marketplace. The IGL members are the one who receives the loan and repays it using garbage. In this case, the IGL members' selection is essential since it will affect all the business process when the members fail to collect the garbage. The selection of members may take some times. According to the BTTM (2018), the members will be given the training regarding the group lending mechanism and selecting the household garbage in 4 days. In day 5 , the IGL operators undergo due diligence using a simple technique based on the contract. IGL operators in this phase give members money, i.e. 1 dollar. As per wadiah contract term and conditions, when operators give 1 dollar money that has series (a number that appears in the bank notes) number 123456 and instruct the potential members to keep it for two days, in the day 7 , operators should receive the actual money with the same series number. If the members fail to give the money back to operators, they are failing in the test and cannot be included in the IGL. Moreover, if potential members pay back the money with another bank notes with different series numbers, the members also fail to pass this test.

Besides the IGL members, the market place role in this business model is quite essential. A market place is a powerful and influential partner since they can connect the IGL operators to the thousand prospective buyers both in the individual and industrial segment. Additionally, it also eases the delivery of the goods produced by the operators by virtue of cooperation with the logistic company. The feature of the application that offered by the market place is also beneficial since they provide the tracking from the delivery of goods to the recipients.

\section{b. Key Activities}


The loan disbursement has an vital role in this model. To minimize the default of the loan given to the members, the account officer or can be called as field officers should prioritize the character of the members, which will be explained more in 4.2. Another significant essential activity is garbage collection. The IGL operator via their field officer should receive it and classify the garbage to help the operations department recycled the waste. Moreover, the process continued by putting the garbage into the recycling machine. Subsequently, the packaging phase will be undergone after the recycled process finish, and the IGL operators finally penetrate the market thru the stipulated channels above.

\section{c. Key Resources}

The primary vital resources are human resources, recycling machine, and storage. The human resource or the account officer who are handling the weekly meeting, collecting the saving, and collecting the garbage. These people are influential to the program due to its duty. Besides the account officer, the IGL should also make some addition of personnel to handle recycling and tackle the marketing of the product. Another resource that IGL Operator should take into account seriously is the recycling machine. This machine is the most significant capital outlay for this program. The IGL operators might raise funding from outside to fulfil this need via voluntary donations like waqf or sadaqah. Another funding alternative for buying the machine is by Islamic bank financing. Storage should be prepared in this program since IGL Operator needs it as the temporary garbage station before processing it and keeping the end product while waiting for the marketing to sell the product.

\section{The Financial Side of Lending Money for Garbage in Return \\ a. Cost Structure}

The cost structure will be divided into the variable cost and the fixed cost. The variable cost of this program is not that significant unless the IGL Operators are offering the Mudharabah based saving program. However, if the IGL operators are also serving the Mudharabah saving, they should pay the variable cost of profit-sharing from the financing revenue.

This program will hit the IGL operators in the fixed cost. This fixed cost will be divided into the capital outlay and the monthly fixed cost. The need for capital outlay is more prominent since the IGL should invest in the recycled and storage. To minimize this cost, IGL operator may rent the machine and storage so that the capital outlay can be downsized. Discussing the monthly fixed cost, there will be change since this program needss more personnel who handle the production process and the marketing processor on the other hand, personnel cost will be hiked.

\section{b. Revenue Stream}

The Revenue stream of this model is wider than the previous model. The orthodox IGL model based on the Qardul Hassan contract will create less revenue if we compare it with this new proposed model. In the new model, the addition of income will be from the cash flow from recycled product sales plus the existing income source from the admin fee and the voluntary donations.

\section{The modus operandi of Lending Money For Garbage In Return program}

This section will scrutinize the phase by phase of this program within figure 4 and the description below: 
a. After the group formation is finished, the IGL members can apply for a loan to the operators by informing them the financial needs and the purpose of the loan. The field officers will handle this application and gives it to the loan committee to be approved.

b. The committee will assess the members' character by looking up his attendance record in the weekly meeting. For those existing members who are wanted to apply for their second loan, the loan record would be analyzed by the committee before they approve the loan.

Figure 4

Modus operandi of "Lending Money For Garbage In Return" program

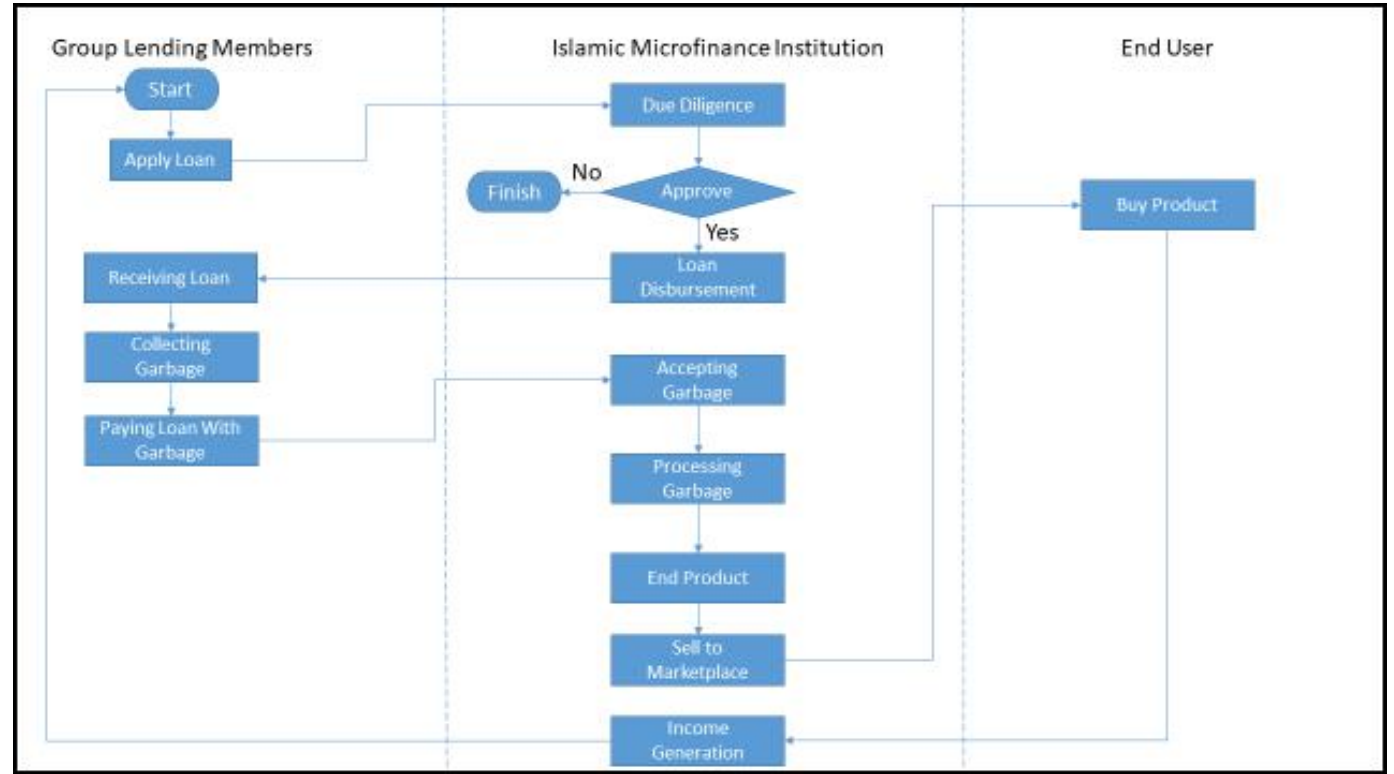

c. If the committee approves the loan proposal, the process continues to the withdrawing the loan

d. On the second, the loan is dropped to the members using the Qardul Hassan ul Hassan. For example, the members apply a loan for $\$ 100$ for 50 weeks, and the committee approves it. The instalment will be $\$ 2$ per week and paid by member in the next 50 weekly meeting and paying it with the garbage with equal value for them.

e. Member starts to collect household garbage to pay the loan in the next following week (third week to the fiftieth week)

f. On the third week, until the loan is finished, the member gives the garbage amounted \$2. It can be plastic garbage, paper garbage or other garbage mutually agreed by both operator and members.

g. The account officer will take the garbage to the office and place it in the storage.

h. The machine personnel that is hired by the IGK operator will take his part in this procedure by classifying the garbage, ie. Organic or inorganic garbage and processed it with the machine.

i. After the end product that resulted from above finished, the marketing personnel appointed by IGL operator will place the offer in the marketplace and the other 
social media like Facebook, Instagram, and WhatsApp and waits until the order come.

j. Whenever a transaction taking place, the marketing personnel will deliver the goods to the buyer

k. Buyer will pay the price of the transaction which contain the cost of good sold and the profit.

1. The proceed from the transaction is plough back to the IGL account to create more loan to its members

\section{E. Conclusion}

The program of "Lending Money For Garbage In Return" is modifying the existing Islamic Group Lending model, mostly based on the Qardul Hassan. The value proposition of this model as stipulated in Business Model Canvas above is to pay the loan with the garbage that has equal value to the instalment amount. For the IGL members, they will get the economic as well as the religious empowerment. At the same time, for the IGL operator side, this will result from value-added and the escalation of their business scale. The operator expectedly will have more income than before due to collecting garbage from the members and processing it to the new product. IGL operators' operation will also widen from only IMFI who gives loan to a social enterprise with lots more product to offer to the end-user. After the recycling process, the IGL Operator might use the market place's network to deliver the product to the end-user (both individual and industry).

This program's main obstacles are the procurement of the recycling machine, the garbage transporter that the operators needed to move the garbage to their storage, and the storage itself. To cater to this problem and provide the sufficient capital outlay, the IGL Operators might create waqf based donations to fund the investment or get financing from another Islamic finance institution. For those IMFI who have limited access to equity, Waqf donations would be feasible for them. However, the more established IMFI can get financing from other IFI to support this program.

This program needs to be taken seriously since two major problems of triple bottom line will be solved: the planet and the people. The sustainability of the planet will be achieved with the circular economy program like "Lending Money For Garbage In Return". Simultaneously, it escalates the welfare of those who are having difficulties fulfilling their daily basic needs.

\section{Bibliography}

Abdelkader, I. Ben, \& Salem, A. Ben. (2013). Islamic vs Conventional Microfinance Institutions : Performance analysis in MENA countries. International Journal of Business and Social Research (IJBSR), 3, 219-233.

Aghion, A. de. (2000). Microfinance Beyond Group Lending. The Economics of Transition, 8(2), 401-420. https://doi.org/10.1111/1468-0351.00049

Anam, A., Jamal, N., \& Sheikh, M. A. (2013). Challenges Faced by the Model of Islamic Microfinance for the Development of Micro Entrepreneurs and SMEs in Rural Pakistan. International SAMANM Journal of Finance and Accounting, 1(3), 17-38.

Armendariz de Aghion, B., \& Morduch, J. (2000). Microfinance Beyond Group Lending. The Economics of Transition, 8(2), 401-420. https://doi.org/10.1111/14680351.00049

Baland, J. M., Somanathan, R., \& Wahhaj, Z. (2013). Repayment incentives and the distribution of gains from group lending. Journal of Development Economics, 105(192), 131-139. https://doi.org/10.1016/j.jdeveco.2013.07.008 
Barder, O. (2009). What Is Proverty Reduction? (170), 1-24. Retrieved from http://www.cgdev.org/content/publications/detail/1421599\%5Cnpapers2://public ation/uuid/F6AFBD47-4CB8-436F-B534-831827DD3793

Behrens, A., Rinaldi, D., Drabik, E., \& Rizos, V. (2016). The Role of Business in the Circular Economy: Markets, Processes and Enabling.

Berg, A., Antikainen, R., \& Hartikainen, E. (2018). Report Of The Finnish Environment Circular Economy for Sustainable Development.

Dusuki, A. W. (2006). Empowering Islamic Microfinance!: Lesson from Group-Based Lending Scheme and Ibn Khaldun' s Concept of 'Asabiyah Empowering Islamic Microfinance!: Lesson from Group-Based Lending Scheme and Ibn Khaldun' s Concept of 'Asabiyah. International Islamic Banking and Finance Conference, 1-18.

Feder, G., \& Huppi, M. (1990). The Role of Groups and Credit Cooperatives in Rural Lending. World Bank Research Observer, 5(2), 187-204.

Francesco Pomponi, \& Alice Moncaster. (2017). Circular economy for the built environment: A research framework. Journal of Cleaner Production, 143, 710-718. https://doi.org/10.1016/J.JCLEPRO.2016.12.055

Geissdoerfer, M., Savaget, P., Bocken, N. M. P., \& Hultink, E. J. (2017). The Circular Economy - A new sustainability paradigm? Journal of Cleaner Production, 143(February), 757-768. https://doi.org/10.1016/j.jclepro.2016.12.048

Ghafar, A., Wan, I., \& Aisyahwan, N. (2013). Group Lending Policy and Repayment Rate in Islamic Microfinance Institutions. IRTI Policy Paper. Retrieved from http://www.irti.org/English/Research/Documents/PP-1435-01.pdf

Johannesen, E., Hvingel, C., Aschan, M., \& Bogstad, B. (2007). Survey based estimation of consumption: spatial and seasonal aspects of cod predation on shrimp. NAFA SCR Document, 07/80, 17.

Khan, A. A. (2008). Islamic Microfinance: TEKUN. (February), 353-365.

Kholis, N. K. (2018). The Prospect Of Islamic Microfinance. Epistemé, (January 2012).

Kodongo, O., \& Kendi, L. G. (2013). Individual lending versus group lending: An evaluation with Kenya's microfinance data. Review of Development Finance, 3(2), 99-108. https://doi.org/10.1016/j.rdf.2013.05.001

Lahti, T., Wincent, J., \& Parida, V. (2018). A definition and theoretical review of the circular economy, value creation, and sustainable business models: Where are we now and where should research move in the future? Sustainability (Switzerland), 10(8). https://doi.org/10.3390/su10082799

Li, S., Liu, Y., \& Deininger, K. W. (2009). How Important are Peer Effects in Group Lending? Estimating a Static Game of Incomplete Information. (319-2016-9947), 30. Retrieved from http://ageconsearch.umn.edu/record/49497

Linderhof, V., Kooreman, P., Allers, M., \& Wiersma, D. (2001). Weight-based pricing in the collection of household waste: The Oostzaan case. Resource and Energy Economics, 23(4), 359-371. https://doi.org/10.1016/S0928-7655(01)00044-6

Macarthur, E. (2013). Towards the Circular Economy Vol. 1. Journal of Industrial Ecology, 1(1), 4-8. https://doi.org/10.1162/108819806775545321

Mega Linarwati, A. F., \& Minarsih, M. M. (2016). Studi Deskriptif Pelatihan Dan Pengembangan Sumberdaya Manusia Serta Penggunaan Metode Behavioral Event Interview Dalam Merekrut Karyawan Baru Di Bank Mega Cabang Kudus. Maharaja Agrasen Institute of Management and Technology Journal of IT \& Management, 2(2). 
Mukhlisin, M (2019) Economic Empowerment \& Poverty Reduction Through Islamic Cooperatives: A Story from Baitut Tamkin Tazkia Madani (BTTM), Bogor, Indonesia. Insight, KNKS, July 2019

Prescott, E. S. (1997). Group lending and financial intermediation: an example. Federal Reserve Bank of Richmond Economic Quarterly Volume, 83(Fall), 23-48.

Schurmann, A. T., \& Johnston, H. B. (2009). The group-lending model and social closure: Microcredit, exclusion, and health in Bangladesh. Journal of Health, Population and Nutrition, 27(4), 518-527. https://doi.org/10.3329/jhpn.v27i4.3398

Son, H. H. (2007). Analyzing and achieving Pro-Poor Growth. International Poverty Centre, (March).

Studies, S. (2016). Leading 121 the cycle Finnish road map to a circular.

Sulipan. (2017). Penelitian Deskriptif Analitis.

Wautelet, T. (2018). The Concept of Circular Economyl: its Origins and its Evolution. (January). https://doi.org/10.13140/RG.2.2.17021.87523. 